Economia e Sociedade, Campinas, Unicamp. IE.

http://dx.doi.org/10.1590/1982-3533.2015v24n2art7

\title{
Comércio internacional e competitividade do Brasil: um estudo comparativo utilizando a metodologia Constant- Market-Share para o período 2000-2011 *
}

\author{
Manuela Gomes de Lima * \\ Marcos Tadeu Caputi Lélis *** \\ André Moreira Cunha ${ }^{* * * *}$
}

\begin{abstract}
Resumo
O presente estudo aplica a metodologia de Constant-Market-Share para analisar o desempenho exportador do Brasil, China, Estados Unidos, Alemanha, Rússia, Coreia do Sul e Japão, entre 2000 e 2011. Após decompor a variação das exportações foi possível constatar que o efeito-competitividade parece ser influenciado pelo padrão de especialização das economias.
\end{abstract}

Palavras-chave: Competitividade; Desempenho exportador; Análise Constant-Market-Share; Brasil; Desenvolvimento.

\begin{abstract}
International commerce and competiveness in Brazil: a comparative study using the Constant-MarketShare methodology for the period 2000-2011

This paper evaluates the export performance of Brazil, China, United States, Germany, Russia, South Korea, and Japan, between 2000 and 2011, based on the recent literature on international competitiveness. By applying the Constant-Market-Share model, it was possible to quantify the contribution of product composition, market distribution and competitiveness on the growth in exports of each country. It was found that growing international demand favoured the commodity exporters as well as countries that prioritized the most dynamic markets (especially Asia). The results on the competitiveness effect were less accurate given that the impact of determinant factors varies according to the specialization pattern of each economy.
\end{abstract}

Keywords: International competitiveness; Export performance; Constant-Market-Share Analysis; Brazil; Development.

JEL F1, O19.

* Trabalho recebido em 14 de dezembro de 2013 e aprovado em 17 de maio de 2015. As opiniões aqui expressas são de responsabilidade exclusiva dos autores e não representam a visão oficial de suas instituições de origem.

** Analista de Negócios Internacionais da Apex-Brasil (Agência Brasileira de Promoção de Exportações e Investimentos), Brasília, DF, Brasil. Email: manuela.lima@gmail.com.

*** Professor do Programa de Pós-Graduação em Economia da Unisinos, São Leopoldo, RS, Brasil. Email: mcaputi@uol.com.br

***** Professor do Departamento de Economia e Relações Internacionais da UFRGS e Pesquisador do CNPq (Conselho Nacional de Desenvolvimento Científico e Tecnológico), Porto Alegre, RS, Brasil. Email: andre.cunha@ufrgs.br. 


\section{Introdução}

As profundas transformações do comércio internacional nos últimos anos trouxeram à tona o debate sobre competitividade internacional. A literatura sobre o tema sugere que são diversos os seus fatores determinantes, com ênfase para aqueles que residem no âmbito da firma, do setor e do ambiente macroeconômico. Da mesma forma, são distintos os impactos daqueles sobre os diferentes segmentos produtivos. Alguns dos estudos enfatizam ainda a existência de uma relação importante entre o padrão de especialização dos países e a sua competitividade internacional (Krugman, 1990, 1996; Guimarães, 1997; Garelli, 2002; Pinheiro; Bonelli, 2011; Kupfer; Hasenclever, 2013; Unido, 2013).

As metodologias de mensuração da competitividade guardam forte ligação com os determinantes para o sucesso competitivo em cada perspectiva analítica considerada. Alguns autores enfatizam a medida de aspectos internos às firmas, buscando avaliar o potencial competitivo das mesmas e dos países em que operam (Haguenauer, 1989; Possas, 1999). Outros pesquisadores optam por indicadores mais amplos, baseados no desempenho das exportações e na evolução do marketshare (Carvalho, 2004; Pinheiro; Bonelli, 2011; Reis; Farole, 2011; WTO, 2012). Entre esses últimos há o modelo de Constant-Market-Share (CMS), que consiste na decomposição da variação das exportações com vistas à identificação dos efeitos da conjuntura internacional, da composição da pauta, da distribuição dos mercados de destino e da competitividade. Com base nessa metodologia, o presente estudo avalia os determinantes do desempenho exportador do Brasil e das seis economias que mais contribuíram para o crescimento das exportações mundiais entre 2000 e 2011. Tal período se caracterizou, dentre outros eventos: (i) pela consolidação de um novo ambiente econômico global, onde a crescente integração comercial e financeira das décadas anteriores foi potencializada; (ii) pela ascensão das principais economias emergentes como polos de dinamismo, implicando em presença crescente na origem da produção e das exportações de mercadorias e serviços; (iii) pela forte elevação nos preços das commodities; e (iv) pela ocorrência da maior crise financeira desde 1929.

Na perspectiva brasileira, aquele período revelou aspectos aparentemente contraditórios: de um lado, particularmente entre 2004 e 2010, e a despeito da crise financeira global, verificou-se a aceleração no crescimento da renda, relativa estabilidade macroeconômica e melhoria no perfil de distribuição da renda; de outro, o avanço nas exportações de mercadorias, com variação nominal de $365 \%$, e ampliação do market-share do Brasil passando de $0,9 \%$ para $1,5 \%$, se deu em meio ao agravamento de tendências prévias de desindustrialização, baixo ritmo de expansão na produtividade e de crescente especialização das exportações em recursos naturais. $\mathrm{O}$ debate recente tem sido intenso sobre em que medida há um quadro de especialização regressiva (Bresser-Pereira, 2010) ou, alternativamente, de 
recomposição de certa normalidade, com o país explorando suas vantagens comparativas (Bach; Bolle, 2013), o que também reflete a discussão em torno das vantagens e desvantagens da especialização produtiva e comercial versus a sua diversificação.

O presente estudo procura contribuir com evidências potencialmente inéditas para a análise do período em tela, ao decompor o crescimento das exportações por meio do método CMS, e comparar o Brasil com outros casos emblemáticos. Verificou-se que o bom desempenho exportador brasileiro se deveu aos efeitos de expansão do mercado internacional com especialização setorial e regional nos segmentos que apresentaram maior dinamismo no período, a saber, a venda de recursos naturais e a diversificação de destinos com ênfase nos mercados emergentes. Além dessa introdução, o trabalho segue com breve revisão da literatura recente sobre o tema e apresentação da metodologia (seção 1), resultados principais (seção 2) e considerações finais.

\section{Revisão da literatura}

\subsection{O modelo de Constant Market Share (CMS)}

Entre as metodologias de avaliação do desempenho das exportações e da competitividade internacional, o modelo de Constant-Market-Share (CMS) é uma das mais flexíveis, pois tem o atributo de decompor o crescimento das exportações entre seus principais componentes (ou causas aparentes). Sua primeira aplicação ao comércio internacional é de Tyszynski (1951),

O método de CMS parte do pressuposto de que o market-share de um país nas exportações mundiais deve se manter constante ao longo do tempo, se suas vendas externas crescerem na mesma velocidade e sentido (em termos de composição da pauta e direcionamento geográfico) que as exportações mundiais. Assim, a diferença entre o crescimento esperado em função dessa hipótese e o crescimento efetivo é atribuída a mudanças na competitividade (Leamer; Stern, 1970). Esta metodologia decompõe o crescimento observado das exportações em quatro efeitos: (i) efeito crescimento do comércio mundial; (ii) efeito composição da pauta, (iii) efeito distribuição de mercados de destino e (iv) efeito competitividade. $\mathrm{O}$ crescimento das exportações mundiais é o benchmark para a avaliação do desempenho exportador de um país. Assim, busca-se verificar em que medida os outros três efeitos foram responsáveis pela diferença entre o crescimento esperado de acordo com a norma de market-share constante e o crescimento efetivo das exportações do país.

O modelo se baseia em uma identidade que equipara a variação no valor das exportações à soma das variações decorrentes do crescimento do comércio mundial, do padrão setorial da pauta de exportações, da orientação geográfica das vendas externas e da competitividade. Ahmadi-Esfahani (2006) pontua que o método 
de CMS não guarda vínculo explícito com nenhuma teoria e que este tipo de formulação, que decompõe os termos de uma identidade, produz resultados empíricos que encontram abrigo em diversas correntes teóricas. A aplicação do método de CMS requer a definição prévia dos recortes setoriais, regionais e temporais que dão forma à identidade mencionada acima, procedimento de onde se originam as principais ressalvas ao modelo.

Leamer e Stern (1970) e Richardson (1971) enfatizam o elevado grau de arbitrariedade inerente à escolha do nível de agregação dos produtos e dos mercados de destino em grupos regionais. Isto implica que a interpretação dos resultados obtidos por meio do CMS é válida apenas para os recortes especificados, não podendo ser generalizada ou transposta para outros contextos.

Richardson (1971) registra ainda o caráter discricionário relativo à ordem de agregação dos termos que compõem a identidade - resultados distintos serão gerados se a ordem em que se calcula os efeitos composição da pauta e mercados de destino for invertida. Outro ponto frágil da metodologia reside no que alguns autores denominam de "problema de número-índice", relacionado à escolha do período-base para o cálculo da variação das exportações. Richardson (1971) aponta a possibilidade de ponderar a variação das exportações pelos valores dos períodos inicial e final, gerando dois conjuntos de resultados, com bases distintas. Sobre esta questão, Canuto e Xavier (2002) assinalam que pode ser válido estabelecer um período de referência para a análise, mas que esta escolha será necessariamente arbitrária e que nenhuma opção resolve por completo o problema, já que ao longo dos anos modificam-se simultaneamente, e com intensidades e direções variáveis, tanto o padrão de especialização do país como o do comércio mundial.

Outra limitação do modelo de CMS é o fato de as exportações serem medidas em valor ${ }^{1}$, o que pode gerar distorções se ocorrerem mudanças nos preços relativos. A depender da elasticidade de substituição, a redução do preço de exportação de um determinado produto (decorrente de redução de custos, por exemplo) pode gerar impacto nulo ou até negativo no market-share do país, mesmo com aumento da quantidade exportada (Canuto; Xavier, 2002). Analogamente, um ciclo de alta nos preços das commodities, por exemplo, contribuirá para ampliar o market-share dos países exportadores desses bens, ainda que não tenha havido mudanças de competitividade ou do quantum exportado.

Por fim, a metodologia de CMS utiliza dados das exportações realizadas, o que confere um caráter retrospectivo aos resultados. Mas Leamer e Stern (1970) argumentam que o método pode ser usado para fazer projeções das exportações e para fazer conjecturas com base nas tendências recentes do comércio internacional.

(1) Richardson (1971) afirma que a medida ideal para calcular as participações de mercado é o quantum exportado, mas que esta opção não é viável devido à indisponibilidade de dados confiáveis de quantidade das exportações. 
A explicitação dessas particularidades é importante na medida em que contribui para a construção de um modelo mais consistente, além de indicar elementos que devem ser pontuados na interpretação dos resultados. Canuto e Xavier (2002) ressaltam que, apesar das limitações que apresenta, o método de CMS oferece um importante ponto de partida para a análise da importância do padrão de especialização setorial, da distribuição dos mercados de destino e dos efeitos dinâmicos sintetizados pelo efeito competitividade no desempenho exportador de um país.

Neste trabalho, opta-se por seguir o modelo proposto por Leamer e Stern (1970), no qual são utilizadas as seguintes definições:

$X^{\prime}=$ valor total das exportações do país A no período 1

$X^{\prime \prime}=$ valor total das exportações do país A no período 2

$X_{i}^{\prime}=$ valor das exportações do país A do bem i no período 1

$X_{i}^{\prime \prime}=$ valor das exportações do país A do bem i no período 2

$X_{j}^{\prime}=$ valor das exportações do país A para o país j no período 1

$X_{j}^{\prime \prime}=$ valor das exportações do país A para o país j no período 2

$X_{i j}^{\prime}=$ valor das exportações do país A para o país j do bem i no período 1

$X_{i j}^{\prime \prime}=$ valor das exportações do país A para o país j do bem i no período 2

$\mathrm{r}=$ crescimento percentual das exportações mundiais entre os períodos 1 e 2

$r_{i}=$ crescimento percentual das exportações mundiais do bem i entre os períodos

1 e 2

$r_{i j}=$ crescimento percentual das exportações mundiais do bem i para o país j entre os períodos 1 e 2

Na primeira versão da construção do modelo de CMS, considera-se que as exportações do país não têm diferenciação por mercadoria ou por destino. Neste nível de análise, o crescimento das exportações do país A é dividido em uma parte relacionada ao crescimento das exportações mundiais (i) e outra associada a um resíduo não explicado (iv), o efeito competitividade, conforme se vê na identidade (1).

$X^{\prime \prime}-X^{\prime} \equiv r \cdot X^{\prime}+\left(X^{\prime \prime}-X^{\prime}-r \cdot X^{\prime}\right)$

Na segunda versão, inclui-se a diversidade de bens que compõe a pauta de exportações do país A. Logo:

$X_{i}^{\prime \prime}-X_{i}^{\prime} \equiv r_{i} \cdot X_{i}^{\prime}+\left(X_{i}^{\prime \prime}-X_{i}^{\prime}-r_{i} \cdot X_{i}^{\prime}\right)$

A identidade acima pode ser agregada, gerando as expressões que seguem:

$X^{\prime \prime}-X^{\prime} \equiv \sum_{i} r_{i} \cdot X_{i}^{\prime}+\sum_{i}\left(X_{i}^{\prime \prime}-X_{i}^{\prime}-r_{i} . X_{i}^{\prime}\right)$ 
$X^{\prime \prime}-X^{\prime} \equiv r \cdot X^{\prime}+\sum_{i}\left(r_{i}-r\right) \cdot X_{i}^{\prime}+\sum_{i}\left(X_{i}^{\prime \prime}-X_{i}^{\prime}-r_{i} \cdot X_{i}^{\prime}\right)$

(ii)

(iv)

Na identidade (2), a variação no valor exportado pelo país A é explicada, basicamente, por três componentes: (i) aumento nas exportações mundiais; (ii) composição da pauta de exportações do país A; e (iv) um resíduo não explicado, que corresponde à diferença entre as exportações efetivas de $\mathrm{A}$ e o valor que teria sido exportado caso o país mantivesse sua participação nas vendas de cada bem ou grupo de bens.

A terceira etapa da construção do método consiste na especificação das exportações do país A por destino. Assim:

$X_{i j}^{\prime \prime}-X_{i j}^{\prime} \equiv r_{i j} \cdot X_{i j}^{\prime}+\left(X_{i j}^{\prime \prime}-X_{i j}^{\prime}-r_{i j} \cdot X_{i j}^{\prime}\right)$

Ao agregar a identidade por grupo de bens e por destinos das exportações, chega-se à expressão (4):

$$
\begin{aligned}
& X^{\prime \prime}-X^{\prime} \equiv \sum_{i} \sum_{j} r_{i j} \cdot X_{i j}^{\prime}+\sum_{i} \sum_{j}\left(X_{i j}^{\prime \prime}-X_{i j}^{\prime}-r_{i j} \cdot X_{i j}^{\prime}\right) \\
& X^{\prime \prime}-X^{\prime} \equiv r \cdot X^{\prime}+\sum_{i}\left(r_{i}-r\right) \cdot X_{i}^{\prime}+\sum_{i} \sum_{j}\left(r_{i j}-r_{i}\right) \cdot X_{i j}^{\prime}+\sum_{i} \sum_{j}\left(X_{i j}^{\prime \prime}-X_{i j}^{\prime}-\right. \\
& \left.r_{i j} \cdot X_{i j}^{\prime}\right)
\end{aligned}
$$

A identidade (4) acrescenta o efeito distribuição de mercados (iii) aos outros componentes já definidos anteriormente. Com isso, são determinados os quatro efeitos que, de acordo com o método de CMS, definem a variação das exportações de um país entre dois períodos. Carvalho (2004) observa que os efeitos (i) e (ii) estão relacionados a fatores externos e (iii) e (iv) refletem fatores internos do país exportador. De fato, o crescimento das exportações mundiais (i) e o efeito composição da pauta (ii) estão fortemente ligados à dinâmica da demanda internacional - total e por bens ou grupos de bens específicos ${ }^{2}$. Já o efeito distribuição de mercados e o efeito competitividade podem estar relacionados, por exemplo, à política comercial adotada e à produtividade do país, respectivamente.

A interpretação da contribuição da composição da pauta e dos mercados de destino para o desempenho exportador de um país é bastante direta, tendo em vista que se baseia no dinamismo das exportações dos setores e das importações dos mercados compradores. O efeito composição da pauta será positivo se o país, no período analisado, concentrar suas exportações nos setores mais dinâmicos do comércio mundial. Já a distribuição dos mercados contribuirá positivamente para a

(2) Muito embora a composição da pauta possa sofrer influência da política industrial do país. 
variação das exportações quando o país se especializar em destinos cujas importações crescem a taxas superiores à média mundial.

No que se refere ao efeito competitividade, a interpretação dos resultados gerados pelo método CMS é mais limitada, por se tratar de um resultado residual, que engloba uma gama de fatores. Leamer e Stern (1970) classificam as variáveis embutidas no efeito competitividade em dois grupos. O primeiro grupo traz as variáveis que impactam a demanda pelos bens exportados, entre eles preços relativos, diferenciais de qualidade, desenvolvimento de novos produtos, estratégia de marketing, capacidade de entrega dos produtos no prazo estipulado, etc. $\mathrm{O}$ segundo grupo de variáveis afeta a oferta dos bens; nesse grupo se incluem diferenciais na taxa de inflação, disponibilidade de fatores de produção, diferenciais de produtividade etc. Os autores sugerem que se faça a regressão do efeito competitividade em relação às variáveis que supostamente o compõem com o objetivo de identificar seu caráter (positivo ou negativo) e magnitude na formação do resíduo.

Ahmadi-Esfahani (2006) defende a utilidade do modelo para a elaboração de um quadro descritivo da evolução das exportações, mas também sugere que os resultados sejam complementados com a aplicação de outros métodos quantitativos, com vistas a uma investigação mais profunda da competitividade internacional dos países.

\subsection{Aplicações do CMS}

Esta subseção apresenta uma revisão não exaustiva da literatura que discute as medidas de desempenho das exportações e as relações que podem ser estabelecidas entre padrão de especialização, desempenho exportador e crescimento da economia. Assim, Imbs e Wacziarg (2003) estudam o padrão de especialização dos países e verificam que, diferentemente do que propaga a teoria tradicional, não existe uma tendência exclusiva de especialização produtiva. $\mathrm{Na}$ verdade eles observaram que até um determinado nível de desenvolvimento econômico (renda per capita de aproximadamente US\$ 9 mil), a estratégia de diversificação é mais vantajosa. A partir desse nível de desenvolvimento, haverá convergência para a especialização da economia. Fagerberg e Srholec (2004) sugerem que os padrões de especialização têm forte correlação ao longo do tempo, confirmando a ideia de que esses padrões, uma vez estabelecidos, tendem a persistir. Também observaram que, entre 1965 e 2002, o comércio de bens intensivos em P\&D cresceu 3\% mais rápido que o dos demais produtos.

Diante deste cenário, Fagerberg e Srholec (2004) utilizam o método CMS para avaliar o desempenho comercial de vinte países da OCDE entre 1965 e 2002, e dos países asiáticos de rápido crescimento econômico entre 1990 e 2002. Os resultados obtidos para os países da OCDE mostraram que a mudança na composição 
da demanda mundial teve efeitos variados entre os países, conforme seus padrões de especialização, e que o efeito adaptabilidade da pauta foi negativo na maioria dos casos, o que se reverteu em perdas de market-share. Nos países asiáticos destacouse o efeito composição dos mercados, positivo para os oito países pesquisados, em virtude do crescimento acelerado do comércio intrarregional. Além disso, esses países apresentaram capacidade adaptativa da pauta positiva, especialmente no setor de eletrônicos.

Buscando verificar o nexo entre o padrão de especialização da produção (e, logo, das exportações) e o crescimento do PIB, Hausmann, Hwang e Rodrik (2005) realizaram um estudo em que examinam o efeito do nível de produtividade das exportações sobre o desempenho econômico futuro dos países. Os autores partem da premissa de que a dotação de fatores naturais e humanos tem forte influência na determinação dos padrões de especialização de uma economia, contudo, defendem que há elementos idiossincráticos que também contribuem para a configuração da estrutura produtiva, tais como as políticas de governo e o cost discovery.

Para o caso do Brasil, Canuto e Xavier (2002) analisam a evolução das pautas de exportação e importação, buscando verificar a relevância dos padrões de especialização setorial sobre o desempenho do comércio exterior nos anos 1980 e 1990. Os autores realizaram um exercício de aplicação do método CMS (ao qual chamam de método de análise estrutural-diferencial ou APCM - Análise com Parcelas de Mercado Constantes) para decompor o resultado das exportações do Brasil naqueles anos.

Partindo da versão definida por Richardson (1971), Canuto e Xavier (2002) observam que o efeito competitividade sofre influência do peso dos setores na estrutura produtiva no período em estudo. Por isso, propõem uma adaptação ao modelo inicial em que o efeito competitividade (termo residual do modelo geral) é decomposto entre efeito competitividade nocional (relativo à parte do efeito competitividade decorrente do padrão de especialização observado no mundo) e efeito alocação (resultante da diferença entre o padrão de especialização do país em estudo e o padrão mundial). Os resultados apontaram para: efeito estrutural setorial negativo, denotando uma tendência de especialização da pauta exportadora brasileira em setores menos dinâmicos que a média mundial; efeito geográfico (distribuição dos mercados de destino) negativo no cálculo baseado no último período, indicativo de orientação das exportações a mercados nacionais menos dinâmicos; efeito alocativo negativo superior ao saldo positivo do efeito competitividade nocional, resultando em efeito competitividade (total) também negativo. Por meio deste exercício, os autores concluíram que o padrão de especialização vigente é um dos elementos que explica a evolução do comércio exterior brasileiro. 
Pereira e Souza (2011) buscaram avaliar as fontes do crescimento das exportações brasileiras entre os anos de 1999 e 2009, utilizando o método CMS, seguindo a forma de cálculo empregada anteriormente por Pinheiro e Bonelli (2007) para analisar a evolução das exportações brasileiras entre 1967 e 2004. Para definir os períodos da análise, Pereira e Souza (2011) seguiram a agregação usada nos estudos de Iglesias e Rios (2010) e Markwald e Ribeiro (2010). A aplicação do método CMS à variação nas exportações brasileiras totais mostrou o dinamismo do comércio mundial como principal fonte do crescimento das vendas externas do Brasil em todos os períodos e no acumulado 1999-2009, com exceção de 1999-2002, quando o efeito competitividade foi maior (respondendo por $83,7 \%$ do aumento das exportações brasileiras). O efeito competitividade foi positivo e expressivo em 20022005 (responsável por 28,3\% da variação no valor exportado), assim como no acumulado 1999-2009 (representou 46,3\% da variação nas exportações). O efeito composição da pauta resultou negativo no primeiro período (-26,2\% da variação nas exportações), mas foi positivo nos períodos subsequentes e também no acumulado 1999-2009 (9,6\%). Já o efeito distribuição dos mercados de destino foi negativo no primeiro período $(-18,9 \%)$ e no acumulado $1999-2009(-6,8 \%)$, ao passo que nos demais períodos foi positivo, mas com pequena participação na variação do valor exportado.

Esta breve revisão sugere que não se pode descartar a priori a possibilidade de existência de relação estreita entre os padrões de especialização, o desempenho comercial e o crescimento econômico dos países. Ademais, revela-se que o método CMS, por sua própria formulação (que decompõe a variação das exportações), é muito flexível, permitindo diversas adaptações que podem incrementar seu poder explicativo.

\section{Aplicação do Modelo CMS para economias selecionadas}

\subsection{Tratamento dos dados e critérios de agregação}

A fonte dos dados brutos de exportação é o United Nations Commodity Trade Statistics Database (UN Comtrade). Os dados das exportações dos países selecionados e do mundo foram coletados por código SH6 (padrão Sistema Harmonizado das Nações Unidas, com detalhamento a seis dígitos) e por país de destino, em dólares correntes. A periodicidade dos dados é anual e cobre o período que vai de 2000 a 2011. Para minimizar o "problema de número índice" explicitado anteriormente, optou-se por calcular ano a ano os componentes da variação das exportações, aplicando sucessivamente as taxas de crescimento aos valores do ano imediatamente anterior e evitando, assim, distorções decorrentes do uso apenas da base do período inicial.

A escolha da agregação setorial a ser empregada levou em conta a literatura acerca dos determinantes da competitividade, que delineia a predominância de 
diferentes fatores conforme o grau de sofisticação tecnológica dos produtos. Assim, as commodities, que são produtos padronizados e de baixo valor agregado, possuem vantagens competitivas pouco dinâmicas, relacionadas à dotação de recursos naturais, enquanto os bens duráveis têm como principal atributo competitivo a diferenciação do produto, que depende da atualização produtiva e do alinhamento com as estratégias das empresas multinacionais (Bertolli; Medeiros, 2003). A produção das indústrias tradicionais sofre grande influência da infraestrutura e da carga tributária, e suas exportações são muito sensíveis a variações na taxa de câmbio; já a competitividade dos produtos mais sofisticados, cujas vendas se destinam a nichos de mercado, tem como fatores determinantes o domínio tecnológico e a qualificação da força de trabalho (Pinheiro; Bonelli, 2011).

Seguindo aproximadamente essas considerações, optou-se por uma agregação setorial baseada na intensidade tecnológica dos produtos, a taxonomia Pavitt $^{3}$, que categoriza os produtos exportados conforme se apresenta no Quadro 1 a seguir.

Quadro 1

Taxonomia Pavitt de classificação de bens por intensidade tecnológica

\begin{tabular}{|c|c|}
\hline Grupo & Descrição \\
\hline Produtos Primários & Agrícolas, Minerais e Energéticos \\
\hline Indústria Intensiva em Recursos Naturais & $\begin{array}{c}\text { Indústria Agroalimentar, Indústria Intensiva em } \\
\text { Outros Recursos Agrícolas, Indústria Intensiva em } \\
\text { Recursos Minerais e Indústria Intensiva em } \\
\text { Recursos Energéticos }\end{array}$ \\
\hline Indústria Intensiva em Trabalho ou & $\begin{array}{c}\text { Bens industriais de consumo não duráveis mais } \\
\text { tradicionais: Têxteis, Confecções, Couro e Calçado, } \\
\text { Cerâmico, Produtos Básicos de Metais, entre outros }\end{array}$ \\
\hline Indústria Intensiva em Escala & $\begin{array}{c}\text { Indústria Automobilística, Indústria Siderúrgica e } \\
\text { Bens Eletrônicos de Consumo* }\end{array}$ \\
\hline Fornecedores Especializados & $\begin{array}{c}\text { Bens de Capital sob Encomenda e Equipamentos de } \\
\text { Engenharia }\end{array}$ \\
\hline Indústria Intensiva em Pesquisa e & $\begin{array}{c}\text { Setores de Química Fina (produtos farmacêuticos, } \\
\text { entre outros), Componentes Eletrônicos, } \\
\text { Telecomunicação e Indústria Aeroespacial }\end{array}$ \\
\hline
\end{tabular}

*Os bens eletrônicos de consumo são especificados em três linhas básicas: (a) Vídeo: televisores, videocassete e câmera de vídeo; (b) Áudio: rádio, auto rádio, cd player, toca-discos, sistema de som, etc.; (c) Outros Produtos: forno de micro-ondas, calculadoras, aparelhos telefônicos, geladeiras, instrumentos musicais, entre outros. Fonte: Holland e Xavier (2004).

O critério de agregação dos países de destino das exportações consistiu em uma combinação de fatores geográficos e econômicos, com o objetivo de estabelecer uma classificação regional capaz de capturar características relevantes dos mercados

(3) Essa metodologia foi elaborada por Pavitt (1984) e ampliada por Holland e Xavier (2004). 
importadores. Assim, chegou-se a uma categorização em que a Europa está dividida entre os países que compõem a União Europeia e os demais países europeus. O critério geográfico prevaleceu nas demais regiões. A delimitação do objeto de estudo desta pesquisa tomou por base o desempenho das exportações dos diversos países entre 2000 e 2011, tendo em vista que neste período os ganhos com a forte expansão do comércio mundial foram desiguais entre as economias. Para tanto, foram calculados o crescimento médio anual das exportações dos países e do mundo, bem como a contribuição de cada país para o crescimento acumulado das exportações mundiais no período em análise. O cálculo da contribuição para o crescimento consiste na multiplicação da participação do país nas exportações mundiais no período inicial pela taxa de crescimento acumulado das suas exportações ao longo do período. A partir desse dado foram selecionadas as seis economias que mais contribuíram para o crescimento do comércio mundial e o Brasil, para efeito de comparação.

O critério de contribuição para o crescimento, ao relacionar o peso da economia no comércio mundial com o dinamismo de suas vendas externas no período, resulta na seleção de países com diferentes perfis. Alemanha, Estados e Unidos e Japão apresentaram crescimento médio anual das exportações inferior à média mundial, mas participam nesta seleção em virtude de sua relevância nos fluxos internacionais de comércio no ano inicial. Já os demais selecionados - China, Rússia e Coreia do Sul (além do Brasil) - detinham participações modestas no início do período, mas suas exportações foram mais dinâmicas que a média mundial, o que levou à ampliação do market-share total de cada um. Tal amostra respondeu por 39\% das exportações mundiais em 2000 e por $41 \%$ em 2011.

Tabela 1

Países que mais contribuíram para o crescimento das exportações mundiais no período 2000-2011 e Brasil

\begin{tabular}{|c|c|c|c|c|c|}
\hline \multirow{2}{*}{$\begin{array}{c}\text { Ranking } \\
\text { contribuição } \\
\text { para o } \\
\text { crescimento }\end{array}$} & \multirow{2}{*}{ País } & \multicolumn{2}{|c|}{$\begin{array}{c}\text { Exportações totais } \\
\text { (em bilhões de US\$) }\end{array}$} & \multirow{2}{*}{$\begin{array}{l}\text { Crescimento } \\
\text { médio anual } \\
2000-2011(\%)\end{array}$} & \multirow{2}{*}{$\begin{array}{c}\text { Contribuição para o } \\
\text { crescimento das } \\
\text { exportações } \\
\text { mundiais entre } 2000 \\
\text { e } 2011(\%)\end{array}$} \\
\hline & & 2000 & 2011 & & \\
\hline 1 & China & 249 & 1.898 & 20,3 & 27,1 \\
\hline 2 & Alemanha & 550 & 1.482 & 9,4 & 15,4 \\
\hline 3 & EUA & 780 & 1.480 & 6,0 & 11,5 \\
\hline 4 & Rússia & 103 & 517 & 15,8 & 6,8 \\
\hline 5 & Coreia do Sul & 172 & 555 & 11,2 & 6,3 \\
\hline 6 & Japão & 479 & 823 & 5,0 & 5,7 \\
\hline \multirow[t]{2}{*}{17} & Brasil & 55 & 256 & 15,0 & 3,3 \\
\hline & Mundo & 6.075 & 17.195 & 9,9 & 183,1 \\
\hline
\end{tabular}

Fonte de dados brutos: UN Comtrade. 
No período entre 2000 e 2011 as exportações mundiais cresceram a uma taxa anual média de 9,9\%. Esse crescimento acelerado das trocas comerciais ocorreu juntamente com fortes transformações na configuração do comércio internacional, manifestas tanto em termos dos bens mais comercializados como da evolução dos mercados exportadores e compradores. Para o presente trabalho, duas informações são indispensáveis: uma diz respeito ao dinamismo dos mercados importadores, aqui representado pela proxy exportações mundiais por regiões de destino; e a outra se refere ao crescimento da demanda por importações de bens de diferentes setores, neste estudo indicada pelas exportações mundiais por setor. As duas tabelas a seguir sintetizam esses dados ${ }^{4}$.

Tabela 2

Evolução das exportações mundiais por região de destino - 2000 a 2011

\begin{tabular}{l|c|c|c|c|c|c|c}
\hline \multirow{2}{*}{ Região de destino } & \multicolumn{2}{|c|}{$\begin{array}{c}\text { Exportações } \\
\text { para a região } \\
\text { (em US\$ } \\
\text { bilhões }\end{array}$} & $\begin{array}{c}\text { Crescimento } \\
\text { médio anual } \\
(\%)\end{array}$ & $\begin{array}{c}\text { Participação } \\
\text { do destino nas } \\
\text { exportações } \\
\text { mundiais } \%)\end{array}$ & $\begin{array}{c}\text { Variação na } \\
\text { participação } \\
\text { (em pontos } \\
\text { percentuais) }\end{array}$ & $\begin{array}{c}\text { Contribuição } \\
\text { para o } \\
\text { crescimento } \\
(\%)\end{array}$ \\
\cline { 2 - 8 } & 2000 & 2011 & 2000 & 2011 & & 1,0 & 6,6 \\
\hline África & 122 & 524 & 14,2 & 2,0 & 3,0 & & \\
\hline América Central e & 75 & 268 & 12,3 & 1,2 & 1,6 & 0,3 & 3,2 \\
Caribe & 1.492 & 2.644 & 5,3 & 24,6 & 15,4 & $-9,2$ & 19,0 \\
\hline América do Norte & 137 & 568 & 13,8 & 2,3 & 3,3 & 1,0 & 7,1 \\
\hline América do Sul & 1.325 & 4.873 & 12,6 & 21,8 & 28,3 & 6,5 & 58,4 \\
\hline Ásia & 79 & 264 & 11,7 & 1,3 & 1,5 & 0,2 & 3,1 \\
\hline Oceania & 133 & 581 & 14,3 & 2,2 & 3,4 & 1,2 & 7,4 \\
\hline Oriente Médio & 155 & 577 & 12,7 & 2,5 & 3,4 & 0,8 & 7,0 \\
\hline Outros & 258 & 1.118 & 14,3 & 4,2 & 6,5 & 2,3 & 14,2 \\
\hline Outros Europeus & 2.299 & 5.778 & 8,7 & 37,8 & 33,6 & $-4,2$ & 57,3 \\
\hline União Europeia & 6.075 & 17.195 & 9,9 & 100,0 & 100,0 & 0,0 & 183,1 \\
\hline Total & & & & & \\
\hline Fonte de
\end{tabular}

Fonte de dados brutos: UN Comtrade.

A análise dos dados da Tabela 2 mostra que as importações da maior parte das regiões cresceram a taxas superiores à média mundial - as exceções foram apenas América do Norte (cujas importações cresceram 5,3\% ao ano, em média) e União Europeia (crescimento médio anual de 8,7\%). Entre as regiões que apresentaram crescimento mais expressivo destacam-se África, Oriente Médio e Outros Europeus, cujas importações evoluíram a taxas superiores a $14 \%$ ao ano.

(4) A partir deste ponto do estudo, as exportações mundiais por destino serão tratadas como importações das regiões e as exportações mundiais por setor serão referidas como importações mundiais de bens do setor, sempre que o uso destas denominações favorecer a interpretação. 
América do Norte e União Europeia continuam sendo grandes mercados importadores, com participação de $15,4 \%$ e 33,6\% no total em 2011, mas perderam importância ao longo do período, ao passo que todas as demais regiões ampliaram sua participação na distribuição das exportações mundiais. O principal destaque é a Ásia, cuja participação enquanto destino das exportações mundiais passou de $21,8 \%$ para $28,3 \%$ entre 2000 e 2011 , apresentando a maior variação na participação $(6,5$ pontos percentuais).

O dado de contribuição para o crescimento apresentado na Tabela 2 confirma estas observações. Sob este ponto de vista, a Ásia se destaca novamente, figurando como o mercado importador que mais contribuiu para o crescimento das exportações mundiais $(58,4 \%$ de contribuição em um total mundial de $183,1 \%)$. Em seguida aparecem União Europeia (com 57,3\% de contribuição), América do Norte (com 19\% de contribuição) e Outros Europeus (14,2\% de contribuição). A segunda colocação da União Europeia se deve ao já mencionado tamanho do mercado e também ao fato de que suas importações cresceram a uma taxa não muito inferior à média mundial. O grupo Outros Europeus, por sua vez, se destaca devido ao acelerado crescimento de suas importações, frente às demais regiões. Estas observações são importantes na medida em que os países que direcionaram suas vendas externas aos mercados importadores mais dinâmicos desfrutaram de ganhos de comércio mais expressivos ao longo do período analisado.

A Tabela 3 exibe os dados de exportações mundiais recortados por setor, conforme a intensidade tecnológica dos bens. A análise desta tabela mostra que três entre as seis categorias setoriais apresentaram crescimento médio anual das importações superior à média geral: produtos primários, intensivos em recursos naturais e intensivos em economias de escala. Sobre os dois primeiros setores, é válido fazer uma ressalva concernente à influência do ciclo recente de alta dos preços das commodities. Entre os anos de 2000 e 2011, o preço das commodities (medido pelo índice geral que agrega commodities agrícolas, alimentos, bebidas, metais e petróleo) aumentou $203,1 \%{ }^{5}$, o que seguramente impactou os valores transacionados desses setores, que são medidos em dólares correntes.

O setor de bens intensivos em economias de escala é o que apresenta maior participação nas importações mundiais $(24,9 \% \text { em } 2011)^{6}$, o que, junto com o crescimento superior à média, conferiu-lhe, também, a maior contribuição para o crescimento mundial $(46,3 \%$ no total de $183,1 \%)$. Os outros três setores cresceram a taxas inferiores à média mundial de $9,9 \%$, mas em nenhum dos casos o crescimento

(5) No mesmo período, o preço das commodities agrícolas cresceu 56\%, o dos metais aumentou 266,4\% e o preço do petróleo subiu 268,4\%. Dados de índices de preços das commodities do World Economic Outlook Database, FMI.

(6) Parte da importância desse setor se deve ao crescente comércio intrafirmas, resultante do aumento dos fluxos de IED 
foi muito inferior a essa taxa de referência. O pior desempenho nesse sentido foi o dos bens intensivos em trabalho, cujas importações cresceram a uma taxa média anual de 7,5\%, revelando-o como o setor menos dinâmico entre os seis. Além disso, este setor foi o que menos contribuiu para o crescimento das exportações mundiais (apenas 15,1\%).

Tabela 3

Evolução das exportações mundiais por intensidade tecnológica - 2000 a 2011

\begin{tabular}{l|c|c|c|c|c|c|c}
\hline & \multicolumn{2}{|c|}{$\begin{array}{c}\text { Exportações } \\
\text { mundiais de bens } \\
\text { Intensidade tecnológica }\end{array}$} & $\begin{array}{c}\text { Crescimento } \\
\text { médio anual } \\
(\%)\end{array}$ & $\begin{array}{c}\text { Participação } \\
\text { do setor nas } \\
\text { exportações } \\
\text { mundiais }(\%)\end{array}$ & $\begin{array}{c}\text { Variação na } \\
\text { participação } \\
\text { (em pontos } \\
\text { percentuais) }\end{array}$ & $\begin{array}{c}\text { Contribui- } \\
\text { ção para o } \\
\text { crescimento } \\
(\%)\end{array}$ \\
\cline { 2 - 8 } & 2000 & 2011 & & 2000 & 2011 & & \\
\hline Produtos Primários & 719 & 2.831 & 13,3 & 11,8 & 16,5 & 4,6 & 34,8 \\
\hline $\begin{array}{l}\text { Intensivos em Recursos } \\
\text { Naturais }\end{array}$ & 732 & 2.540 & 12,0 & 12,0 & 14,8 & 2,7 & 29,8 \\
\hline Intensivos em Trabalho & 751 & 1.668 & 7,5 & 12,4 & 9,7 & $-2,7$ & 15,1 \\
\hline $\begin{array}{l}\text { Intensivos em } \\
\text { Economias de Escala }\end{array}$ & 1.464 & 4.277 & 10,2 & 24,1 & 24,9 & 0,8 & 46,3 \\
\hline Fornecedores & 1.137 & 2.706 & 8,2 & 18,7 & 15,7 & $-3,0$ & 25,8 \\
\hline Especializados & 1.028 & 2.357 & 7,8 & 16,9 & 13,7 & $-3,2$ & 21,9 \\
\hline Intensivos em P\&D & 244 & 816 & 11,6 & 4,0 & 4,7 & 0,7 & 9,4 \\
\hline Não classificados & 6.075 & 17.195 & 9,9 & 100,0 & 100,0 & 0,0 & 183,1 \\
\hline Total & & & & & & \\
\hline
\end{tabular}

Fonte de dados brutos: UN Comtrade.

Os dois setores mais intensivos em tecnologia - fornecedores especializados e intensivos em P\&D - registraram perda de participação nos fluxos de importações totais, em decorrência de taxas de crescimento inferiores à média (8,2\% e 7,8\% ao ano, respectivamente). No entanto, se somadas suas contribuições para o crescimento total, chega-se a $47,7 \%$ em um total de $183,1 \%$. Em relação à distribuição setorial das exportações mundiais, dois pontos merecem destaque. $\mathrm{O}$ primeiro é que, em comparação com a evolução das exportações por regiões de destino, as exportações por setores apresentaram resultados mais homogêneos em termos de taxas de crescimento e participação no total. $O$ outro ponto é que, não fosse a forte alta nos preços das commodities, provavelmente os resultados seriam ainda mais equilibrados.

Esta breve análise da evolução do comércio mundial entre 2000 e 2011 é importante na medida em que esses dados (de resultado total, por destinos e por setores) constituem o benchmark do modelo de CMS. A partir dessas observações é possível explicar, pelo menos em parte, os resultados que serão apresentados a 
seguir. De um modo geral, espera-se melhor desempenho no comércio exterior em países que direcionaram suas exportações para: (i) mercados mais dinâmicos; e/ou (ii) bens cuja demanda cresce mais rapidamente.

\subsection{A Aplicação do CMS ao caso do Brasil}

O Brasil foi um dos países que registrou crescimento das exportações acima da média entre 2000 e 2011, com taxa de $15 \%$ ao ano. Entre os países analisados, apenas Brasil e China tiveram mudanças significativas na composição da pauta. Em 2000, o setor que detinha maior participação nas exportações brasileiras era o de bens intensivos em economias de escala, com $26,1 \%$, seguido de intensivos em recursos naturais e produtos primários, que respondiam respectivamente por $20,9 \%$ e $19,6 \%$ da pauta total. Os produtos intensivos em P\&D e intensivos em trabalho também tiveram participação significativa neste ano, de 11,4\% e 10,7\%. A grande mudança que ocorreu na pauta de exportações brasileiras foi o gradativo aumento da relevância dos produtos primários nas exportações - este setor foi responsável por 45,2\% do valor das exportações brasileiras em 2011. A parcela dos bens intensivos em recursos naturais ficou praticamente estável, enquanto os demais setores reduziram sua participação na pauta total. Neste último ano a parcela do setor de intensivos em economias de escala ainda foi alta, correspondendo a 18,6\% do total. Mas o fato é que houve um movimento de concentração setorial das exportações em produtos primários.

Também ocorreram mudanças marcantes em relação aos destinos das exportações brasileiras. No primeiro ano da análise, os países da América do Norte e da União Europeia eram os principais importadores dos produtos brasileiros, e a eles eram direcionados $28,4 \%$ e $28 \%$ das vendas do Brasil, respectivamente. A América do Sul foi a terceira região que mais importou bens produzidos no Brasil, absorvendo 20,2\% das exportações do país. A Ásia já era um importante parceiro, destino de $11,5 \%$ das exportações brasileiras, mas pouco expressivo se comparado à sua participação de 30,1\% no total exportado em 2011 (a partir de 2009 a Ásia se tornou a principal região de destino das exportações brasileiras). Entre 2000 e 2011 os outrora principais destinos das exportações brasileiras perderam importância relativa - a América do Norte foi o destino de apenas 12,9\% das exportações brasileiras em 2011, enquanto União Europeia e América do Sul receberam 20,7\% e $17,7 \%$ das vendas externas do Brasil. As economias da África e do Oriente Médio aumentaram sua relevância nas exportações brasileiras e cada uma absorveu 4,8\% do total exportado em 2011.

A aplicação do modelo de CMS para decompor a variação anual das exportações brasileiras traduz os resultados dessas mudanças (Tabela 4; Gráfico 1, painel A). O crescimento do comércio mundial, como esperado, foi o principal componente da variação das exportações brasileiras. Os outros efeitos também foram 
positivos e tiveram participação importante no crescimento das exportações do Brasil. O efeito positivo da composição da pauta reflete a maior concentração das exportações em produtos primários, que foram os que apresentaram maior dinamismo no comércio mundial no período 2000-2011. Já o efeito distribuição dos mercados de destino é explicado pela mudança na orientação regional dos produtos exportados pelo Brasil. Entre 2000 e 2011, aumentou a parcela das exportações brasileiras direcionadas para a Ásia, principalmente, e também para outros mercados mais dinâmicos que a média mundial, como África e Oriente Médio. Ao mesmo tempo, encolheu a parcela das exportações destinadas aos mercados menos dinâmicos da América do Norte e da União Europeia.

Quanto à evolução do market-share (painel B - Gráfico 1), o Brasil logrou ampliação expressiva apenas nos setores menos intensivos em tecnologia, com ganho de 2,6 pontos percentuais nas exportações mundiais de produtos primários e 0,4 ponto percentual de ganho nos bens intensivos em recursos naturais. Nos demais setores, o market-share do Brasil ficou praticamente estável, com ganhos e perdas variando entre 0,1 e 0,2 ponto percentual. Em relação ao market-share do Brasil nos mercados importadores, os maiores ganhos foram registrados nos mercados da América Central e Caribe (1,6 ponto percentual), África (1,2 ponto), Ásia (1,1 ponto) e Oriente Médio (1,1 ponto). A participação do Brasil nos demais mercados variou mais discretamente.

Tabela 4

Decomposição do crescimento das exportações brasileiras (em bilhões de US\$) - 2001-2011

\begin{tabular}{c|c|c|c|c|c}
\hline \multirow{2}{*}{ Ano } & \multirow{2}{*}{$\begin{array}{c}\text { Variação das } \\
\text { exportações }\end{array}$} & $\begin{array}{c}\text { Crescimento } \\
\text { do comércio } \\
\text { mundial }\end{array}$ & $\begin{array}{c}\text { Composição } \\
\text { da pauta }\end{array}$ & $\begin{array}{c}\text { Distribuição dos } \\
\text { mercados de } \\
\text { destino }\end{array}$ & Competitividade \\
\hline 2001 & 3,2 & $-1,8$ & 0,1 & 0,1 & 4,8 \\
\hline 2002 & 2,2 & 3,3 & $-0,1$ & $-2,0$ & 1,0 \\
\hline 2003 & 12,8 & 10,2 & 0,6 & $-1,9$ & 3,8 \\
\hline 2004 & 23,5 & 15,6 & 0,2 & 1,9 & 5,7 \\
\hline 2005 & 21,9 & 12,4 & 4,0 & 2,8 & 2,6 \\
\hline 2006 & 19,3 & 20,0 & $-0,2$ & 3,2 & $-3,7$ \\
\hline 2007 & 22,8 & 19,4 & 1,9 & $-1,9$ & 3,4 \\
\hline 2008 & 37,3 & 25,1 & 9,8 & 11,4 & $-8,9$ \\
\hline 2009 & $-44,9$ & $-43,7$ & $-7,4$ & 3,9 & 2,3 \\
\hline 2010 & 44,4 & 31,3 & 1,8 & 8,7 & 2,6 \\
\hline 2011 & 58,7 & 38,6 & 17,8 & 3,2 & $-0,9$ \\
\hline $\begin{array}{c}\text { Acumulado } \\
2001-2011\end{array}$ & 200,9 & 130,3 & 28,5 & 29,4 & 12,8 \\
\hline Fonyyyyy & & & & & \\
\hline
\end{tabular}

Fonte de dados brutos: UN Comtrade. 


\section{Gráfico 1}

Exportações Brasileiras: fontes de crescimento e market-share, 2000-2011

(A) Fontes do crescimento das exportações

- acumulado 2001-2011

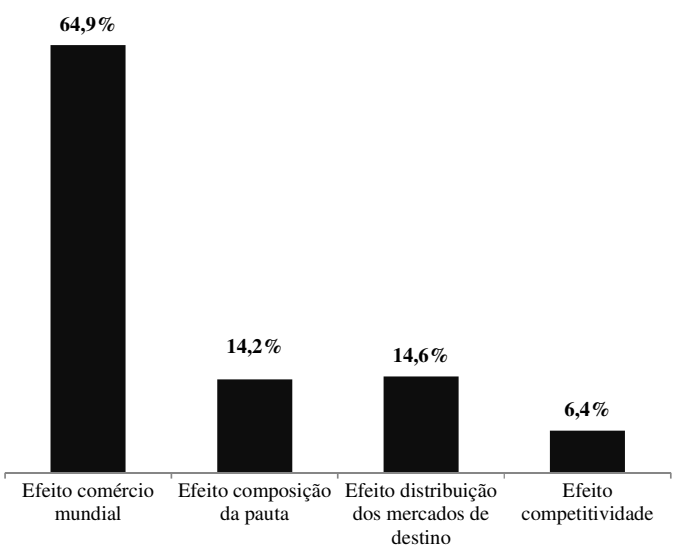

(B) Evolução do market-share setorial nas

Exportações mundiais - 2000 e 2011

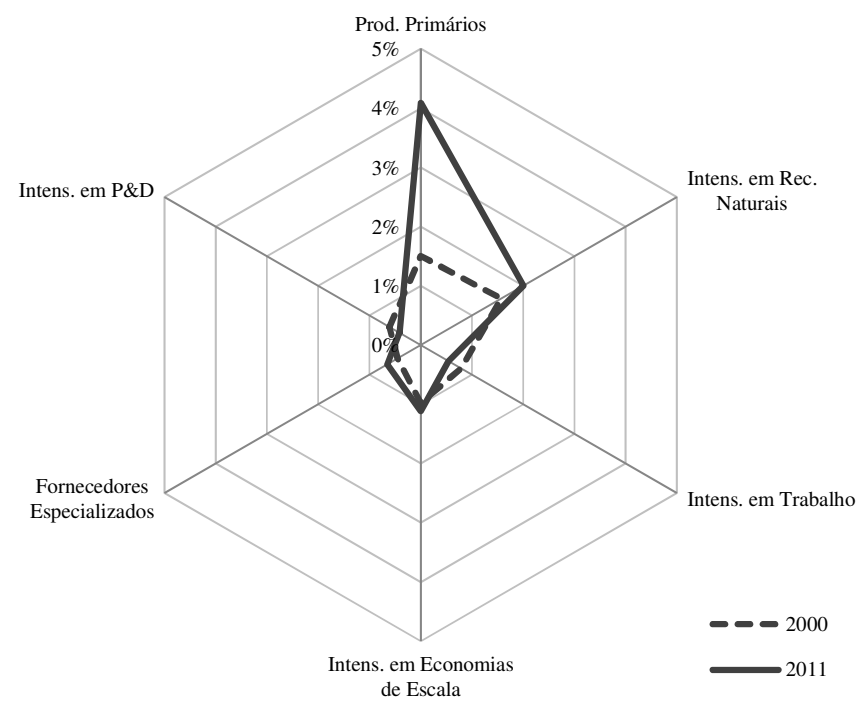

Fonte de dados brutos: UN Comtrade.

O resultado geral das mudanças ocorridas nas exportações brasileiras no período analisado, tanto relacionadas à composição da pauta como aos mercados de destino, foi a ampliação do market-share total do país nas exportações mundiais, que passou de 0,9\% para 1,5\% entre 2000 e 2011. 


\subsection{A aplicação do CMS aos demais países selecionados}

Os Gráficos A1 e A2, em anexo, fornecem os resultados da aplicação da metodologia do CMS e da análise da evolução da participação de mercado nos distintos setores nas demais economias selecionadas neste estudo. Entre elas, a China foi a que apresentou o desempenho exportador mais notável no período entre 2000 e 2011 , com taxa média de crescimento anual de $20,3 \%$, frente a uma média mundial de $9,9 \%$. Ademais, houve mudanças na composição da pauta de exportações da China, que se tornou gradativamente mais intensiva em bens de maior conteúdo tecnológico. A participação somada de produtos primários, intensivos em recursos naturais e intensivos em trabalho caiu de $51,5 \%$ para $35,3 \%$ do total das vendas externas do país. Ao mesmo tempo, aumentou a relevância dos bens intensivos em economias de escala, fornecedores especializados e intensivos em P\&D, cuja participação somada no total exportado elevou-se de 48,3\% para 64,6\% entre 2000 e 2011. Ainda assim, os bens intensivos em trabalho ocuparam a primeira posição entre os setores exportados pela China durante todo o período, com participação de $26,3 \%$ no último ano analisado.

Em relação às regiões de destino das exportações chinesas, a Ásia se manteve na primeira posição em todos os anos, embora tenha perdido participação, absorvendo 50,4\% das vendas externas chinesas em 2000 e 42,4\% em 2011. A América do Norte também perdeu importância relativa: em 2000, 22,7\% das exportações chinesas destinavam-se a essa região, ao passo que em 2011 essa participação caiu para 19,7\%. Ainda assim, a América do Norte continua sendo o segundo principal destino regional das vendas chinesas. A redução de 11,1 pontos percentuais na participação destas duas regiões somadas foi distribuída entre outros mercados, principalmente América do Sul e União Europeia (estas regiões ampliaram suas participações nas exportações chinesas em 2,5 e 2,3 pontos percentuais, respectivamente), com esta última mantendo a terceira posição entre as regiões de destino. Entre 2000 e 2011 aumentou também a relevância dos demais mercados, que somados ampliaram sua participação de $8,4 \%$ para $15,2 \%$ das exportações chinesas.

Assim, no que tange à distribuição das exportações por mercados, verificase que, à exceção do aumento do peso da União Europeia, houve um movimento geral de desconcentração dos destinos das vendas externas chinesas. A análise do Gráfico A1 (painel B) confirma a predominância da expansão do comércio mundial entre as fontes do crescimento das exportações chinesas. Ao mesmo tempo, coloca em evidência a enorme contribuição do efeito competitividade, do qual decorreu quase metade da variação das exportações no período 2000-2011. O efeito composição da pauta revelou-se negativo, o que pode ser explicado pela redução da participação dos bens primários e intensivos em recursos naturais (cujas importações cresceram bastante acima da média mundial no período), bem como pela 
preponderância do setor de intensivos em trabalho na pauta total da China (sendo que este foi o setor menos dinâmico entre os seis analisados, crescendo apenas 7,5\% ao ano frente a uma média mundial de 9,9\%). Quanto ao efeito distribuição dos destinos das exportações, o resultado positivo denota o acerto da estratégia de desconcentração de mercados; ao mesmo tempo, sua reduzida magnitude pode ser reflexo do maior direcionamento das exportações chinesas para a União Europeia e da grande participação da América do Norte entre os destinos - ressalte-se que estes foram os únicos mercados regionais cujas importações cresceram abaixo da média mundial no período.

Uma abordagem complementar aos resultados do modelo de CMS é o da evolução do market-share das exportações chinesas no mercado mundial (painel B, Gráfico A2). Observa-se o aumento da participação chinesa nas exportações mundiais dos quatro setores de maior conteúdo tecnológico entre 2000 e 2011. Partindo da premissa de que o market-share expressa a competitividade das exportações de um país, conclui-se que o desempenho chinês foi muito superior à média. Os ganhos de market-share do país entre 2000 e 2011 se distribuíram da seguinte forma: 17,2 pontos percentuais no setor de bens intensivos em trabalho; 6,9 pontos em bens intensivos em economias de escala; 14,5 pontos em bens de fornecedores especializados; e 9,7 pontos percentuais em bens intensivos em P\&D.

Também em relação ao market-share detido nos mercados importadores, os resultados da China são notáveis. O país ampliou sua participação nas compras externas de todas as regiões, com destaque para América do Norte, América do Sul e Oceania, regiões em que o ganho de market-share da China no período foi maior que 10 pontos percentuais. Também nos mercados da África, Oriente Médio e Ásia, a China ampliou fortemente sua participação - em 9,8, 9,1 e 7,0 pontos percentuais, respectivamente. Na União Europeia e Outros Europeus, as mercadorias chinesas ganharam aproximadamente 4,5 pontos percentuais de participação de mercado ao longo do período, partindo de um market-share inferior a $2 \%$ e alcançando mais de 6\% em 2011 nas duas regiões.

Ao final de 2011, a China era a fornecedora de 16,5\% dos bens importados pelos países asiáticos, 15,5\% das importações da Oceania e 14,2\% das compras externas da América do Norte; além disso, registrou participação de mercado superior a $13 \%$ na África, Oriente Médio e América do Sul. A evolução do marketshare total da China, que passou de $4,1 \%$ para $11 \%$ das exportações mundiais entre 2000 e 2011, atesta a superioridade de seu desempenho frente às demais economias exportadoras, o que se confirmará nas subseções a seguir.

Entre os países que mais contribuíram para o crescimento das exportações mundiais entre 2000 e 2011, a Alemanha figurou na segunda colocação. Esse resultado se deveu, principalmente, à magnitude do valor das suas exportações no 
ano inicial, já que as vendas externas do país cresceram, nos onze anos analisados, a uma taxa de 9,4\% ao ano, um pouco inferior à média mundial. A composição da pauta de exportações alemãs variou pouco ao longo do período, mantendo-se a predominância dos setores mais intensivos em tecnologia. Em relação aos destinos das exportações, os países da União Europeia continuaram sendo os principais mercados da Alemanha, mas sua participação nas vendas externas caiu de 63,3\% para 58,2\% ente 2000 e 2011. A América do Norte, que no início do período era a segunda principal região de destino das exportações alemãs (11,6\% de participação), também perdeu participação e em 2011 foi o destino de 8,4\% das vendas externas alemãs, ficando então na quarta posição. A redução da importância dessas duas regiões foi compensada por um maior direcionamento das exportações alemãs para Ásia e Outros Europeus - cuja participação em 2011 foi de 13,2\% e 11,8\%, respectivamente. A parcela destinada às demais regiões ficou praticamente estável durante o período analisado. Esses dados mostram que houve uma mudança sutil na orientação das exportações alemãs, no sentido de mercados mais dinâmicos.

Como suas vendas externas cresceram a uma taxa próxima à média mundial e a composição da pauta se manteve praticamente estável no período, a Alemanha logrou manter - e até ampliar discretamente - seu market-share nas exportações mundiais dos setores em que é especialista. Em relação à participação da Alemanha nas exportações mundiais por setores, as mudanças ficaram por conta da ampliação de seu market-share nos bens de fornecedores especializados e intensivos em P\&D (aumento de 1,5 e 1,7 pontos percentuais, respectivamente) e na redução da sua participação no comércio mundial de produtos intensivos em recursos naturais.

Quanto ao market-share da Alemanha nos mercados importadores, houve ganhos modestos nas regiões América do Norte, Ásia e Oceania. Nas demais regiões o país perdeu participação de mercado, principalmente na África, Outros Europeus e Oriente Médio, com perdas de respectivamente 2,2, 1,8 e 1,3 pontos percentuais. Os dados apresentados mostram que a Alemanha, além de ter ampliado suas exportações a uma taxa próxima da média mundial, conservou sua posição no comércio internacional sem que precisasse modificar o perfil de suas vendas externas, tradicionalmente baseadas em bens de maior conteúdo tecnológico.

Entre os países selecionados, Estados Unidos foi o que apresentou a segunda menor taxa de crescimento das exportações entre 2000 e 2011, com uma média anual de $6 \%$. No ano 2000, os principais setores da pauta de exportações estadunidense foram os de bens intensivos em P\&D (26,4\%), fornecedores especializados $(25,6 \%)$ e intensivos em economias de escala $(20,4 \%)$, somando $72,3 \%$ do total. Em 2011 estes três setores continuaram na dianteira, mas seu somatório caiu para $58,4 \%$ e inverteu-se a ordem de importância dos mesmos na pauta: intensivos em economias de escala representaram $24,3 \%$ do total, 
fornecedores especializados responderam por $18 \%$ e intensivos em P\&D por $16,1 \%$. Ao longo do período, houve redução da parcela na pauta correspondente a bens intensivos em trabalho e aumento da participação de produtos primários e intensivos em recursos naturais (a participação destes dois, somada, evoluiu de 16,1\% para 27,2\%), indicando algum alinhamento da composição da pauta estadunidense na direção dos setores que tiveram desempenho mais dinâmico no comércio mundial entre 2000 e 2011.

Movimento semelhante observou-se na distribuição dos destinos das exportações, com redução da importância relativa dos mercados da América do Norte e da União Europeia e aumento da participação das demais regiões. No entanto, deve-se frisar que a América do Norte permanece como principal região de destino (32,4\% de participação em 2011) e que a União Europeia se sustentou na terceira posição ao longo de todo o período (e foi o destino de 18,2\% das vendas no último ano). A Ásia se manteve na segunda posição e no último ano absorveu $25,9 \%$ das exportações estadunidenses. A América do Sul ganhou importância e sua parcela nas exportações dos Estados Unidos partiu de 4,7\% para 7,7\% entre 2000 e 2011. A variação na participação das demais regiões foi mais sutil.

A aplicação do modelo de CMS à variação das exportações dos Estados Unidos complementa estas observações e traz um dado adicional, referente à perda de competitividade das vendas externas desse país, qual seja: o crescimento das suas exportações foi efeito mais que exclusivo da ampliação das trocas comerciais no mundo. Embora o país tenha conseguido direcionar suas vendas a destinos mais dinâmicos, não o fez com intensidade suficiente para que o efeito distribuição dos destinos fosse positivo. A composição da pauta, onde predominam bens de maior conteúdo tecnológico, também não colaborou com as exportações estadunidenses. Mas o que mais se destaca é a magnitude das perdas relativas ao efeito competitividade. Como resultado de seu mau desempenho comercial entre 2000 e 2011, os Estados Unidos perderam market-share em todos os setores exportados, principalmente nos dois mais intensivos em tecnologia.

O caso da Rússia se assemelha ao do Brasil. Entre 2000 e 2011 as exportações russas cresceram a uma taxa média de $15,5 \%$ ao ano, bastante superior à média mundial de 9,9\%. Todavia, há uma distinção importante: suas vendas externas são extremamente concentradas em produtos primários e intensivos em recursos naturais - a soma da participação desses dois setores no total exportado foi de 60,9\% em 2000 e passou para 76,3\% em 2011. Estes foram os setores mais dinâmicos nas exportações mundiais no período analisado e sua preponderância absoluta na composição da pauta russa reverteu-se em ganhos expressivos no 
comércio exterior ${ }^{7}$. O outro setor que tem algum destaque nas exportações russas é o de bens intensivos em economias de escala - mas sua parcela no total caiu de $19,1 \%$ para $10,2 \%$ entre 2000 e 2011 . Os demais setores mantiveram participação pouco significativa ao longo do período.

No que tange aos destinos de suas vendas, o principal mercado regional da Rússia entre 2000 e 2011 foi a União Europeia, para onde o país direcionou $41 \%$ de suas vendas em 2000 e 44,4\% em 2011. Dois mercados que também tiveram destaque foram Outros Europeus e Ásia, que no primeiro ano do período absorviam praticamente a mesma parcela das exportações russas - respectivamente $13,5 \%$ e 13\%. Ademais, ampliou-se relevância da Ásia, enquanto a fatia destinada a Outros Europeus se manteve estável. As demais regiões tiveram peso menor entre os destinos das vendas russas, mas vale a pena observar que entre 2000 e 2011 houve redução na parcela direcionada à América Central e Caribe e à América do Norte.

Neste período, as exportações russas aumentaram em US\$ 413,9 bilhões, com contribuição positiva do comércio mundial, composição da pauta, distribuição dos mercados e competitividade em quase todos os anos. Assim como se verificou para os países apresentados anteriormente, o efeito crescimento do comércio mundial foi o principal fator no aumento das vendas externas, mas no caso da Rússia fica evidente a importância da composição da pauta no resultado total. Os ganhos relacionados à composição da pauta se explicam pelo fato de as exportações da Rússia terem crescido no sentido dos setores mais dinâmicos do comércio mundial. A pauta, que já era concentrada em commodities, tornou-se ainda mais intensiva nesses bens ao longo do período.

Em relação ao componente distribuição dos mercados de destino, o resultado positivo decorre do maior direcionamento das exportações russas para a Ásia e a União Europeia. Observe-se que estas duas regiões importadoras foram as que mais contribuíram para o crescimento das exportações mundiais no período estudado - a primeira devido ao montante e ao dinamismo de suas importações e a segunda por ser o maior mercado importador regional do mundo. O outro elemento que merece consideração é o efeito competitividade, que teve participação de $6,8 \%$ no aumento das exportações russas. Verificou-se forte expansão de seu market-share nos setores de produtos primários e intensivos em recursos naturais (Gráfico A2, painel F). Nos demais setores, seu market-share se manteve estável. Quanto ao market-share por regiões, os maiores ganhos da Rússia se deram na União Europeia (2,1 pontos percentuais), Ásia (1,1 pontos percentuais) e Outros Europeus (aumento

(7) Vale ressaltar que neste estudo a evolução das exportações dos países é medida em dólares correntes. Assim, as economias cuja pauta de exportações é intensiva em commodities foram evidentemente favorecidas pelo ciclo de alta dos preços internacionais das mesmas. 
de 1 ponto percentual). Nas exportações totais, a Rússia ampliou sua participação de $1,7 \%$ para $3 \%$ das exportações mundiais.

As exportações da Coreia do Sul cresceram a uma taxa superior à média mundial, alcançando a marca de $11,2 \%$ ao ano em média. Sua pauta de exportações caracteriza-se pela predominância dos setores mais intensivos em tecnologia, com destaque para os bens intensivos em economias de escala, que durante todo o período estiveram na primeira posição entre os seis setores analisados. A participação destes produtos na pauta sul-coreana evoluiu de $32 \%$ para $42,8 \%$ entre 2000 e 2011 . No mesmo período, os setores de bens intensivos em P\&D e de fornecedores especializados perderam importância relativa na composição da pauta, mas mantiveram elevada participação - 20,9\% e 15,8\% no total exportado em 2011, respectivamente. Reduziu-se ainda a participação dos bens intensivos em trabalho (de 14,2\% em 2000 para 4,2\% em 2011) e aumentou a parcela das exportações composta por intensivos em recursos naturais (de $10,5 \%$ para $15,7 \%$ no mesmo período).

No que diz respeito aos destinos das vendas externas da Coreia do Sul, as principais mudanças ocorridas no período foram o aumento do direcionamento das exportações para a Ásia e a concomitante redução da participação dos países da América do Norte e da União Europeia no total exportado. A Ásia absorveu 56,5\% das exportações da Coreia em 2011 (contra 47,1\% no ano 2000), enquanto a América do Norte, que era o destino de $24,7 \%$ das vendas do país em 2000 , respondeu por apenas $13,1 \%$ em 2011. No mesmo período a parcela da União Europeia caiu de $14,5 \%$ para $10,1 \%$. Nos demais mercados houve mudanças menos significativas. A decomposição da variação das exportações da Coreia do Sul apresentada no painel C (Gráfico A1) mostra que a pauta de exportações coreanas se manteve intensiva em bens relativamente pouco dinâmicos, de modo que, em termos setoriais, suas exportações cresceram em sentido contrário ao do crescimento do comércio mundial. Assim, a composição da pauta do país foi o único componente que contribuiu negativamente com a variação das exportações totais no período. As escolhas relativas à distribuição dos mercados de destinos foram mais bem-sucedidas, com uma maior concentração das vendas nos mercados asiáticos, e este elemento foi responsável por quase $10 \%$ do aumento das exportações da Coreia do Sul.

$\mathrm{O}$ efeito crescimento do comércio mundial foi mais uma vez dominante, mas o destaque, no caso da Coreia, é a participação de $11,7 \%$ do efeito competitividade na evolução das suas exportações. Este país conseguiu, mesmo em um cenário mais favorável às exportações de bens primários e intensivos em recursos naturais, sustentar e ampliar seu market-share nas exportações mundiais de bens intensivos em economias de escala, de fornecedores especializados e intensivos em P\&D (painel C, Gráfico A2). O que se conclui desta análise é que o principal trunfo da Coreia do Sul foi conseguir aumentar o direcionamento das suas exportações para 
a Ásia e acompanhar o crescimento das importações dessa região, posicionando-se como fornecedor de bens intensivos em tecnologia.

Entre os sete países selecionados neste estudo, o Japão foi o que apresentou o pior desempenho no crescimento das exportações totais, com uma taxa média de crescimento anual das suas vendas externas de 5\% ao ano entre 2000 e 2011. Ao longo desses anos a pauta de exportações do Japão se manteve intensiva em bens de maior conteúdo tecnológico. Os bens intensivos em economias de escala, de fornecedores especializados e intensivos em P\&D, somavam 87,2\% das exportações em 2000 e passaram para $84 \%$ da pauta em 2011. Durante este período, aumentou a participação do setor de intensivos em economias de escala (de $35,1 \%$ para $41,1 \%$ ) e encolheu a dos outros dois. Todavia, o perfil geral da composição da pauta se preservou. Com relação aos destinos das exportações, houve mudanças semelhantes às que ocorreram na Coreia do Sul. A Ásia continuou sendo a principal região de destino das vendas do Japão, mas sua participação nas exportações do país aumentou de $41,2 \%$ para $56,1 \%$ entre 2000 e 2011, ao mesmo tempo em que diminuiu a relevância dos mercados da América do Norte e da União Europeia.

Conforme se observa no Gráfico A1 (painel E), praticamente toda a variação das exportações japonesas entre 2000 e 2011 decorreu do crescimento do comércio mundial. Ademais, o efeito competitividade teve uma enorme participação negativa no resultado geral. Este quadro se confirma com a análise da evolução da participação de mercado do Japão nas exportações mundiais (Gráfico A2, painel E): durante o período em estudo, o país perdeu market-share em todos os setores exportados, principalmente naqueles em que sua pauta é mais concentrada - o país perdeu 3,6 pontos percentuais de participação nas exportações mundiais de bens intensivos em economias de escala, 4,2 pontos em fornecedores especializados e 5 pontos percentuais nos intensivos em $\mathrm{P} \& \mathrm{D}$. O país também registrou perda de participação em todas as regiões importadoras (exceto apenas em Outros Europeus, onde seu market-share ficou estável), o que resultou na redução de seu market-share total nas exportações mundiais, que caiu de 7,9\% em 2000 para 4,8\% em 2011.

\section{Considerações finais}

A aplicação do modelo de Constant-Market-Share para aferir o desempenho exportador do Brasil, China, Estados Unidos, Alemanha, Rússia, Coreia do Sul e Japão apresentou resultados consistentes com a dinâmica atual do comércio internacional, em que prevaleceu o efeito crescimento do comércio mundial entre as causas do desempenho exportador.

O efeito composição da pauta foi positivo apenas para os países cujas exportações cresceram no sentido dos bens primários e intensivos em recursos naturais que, entre os sete aqui analisados, foram apenas Brasil e Rússia. Estes dois 
países se beneficiaram do ciclo de alta dos preços das commodities decorrente da demanda dos países asiáticos em desenvolvimento por esses bens. O resultado do efeito distribuição dos destinos foi positivo para os países que fizeram a opção de direcionar suas exportações para os mercados mais dinâmicos como África, Oriente Médio e, principalmente, Ásia ou para os que conseguiram ampliar significativamente seu market-share no grande mercado importador da União Europeia. Já o efeito competitividade se revelou positivo somente na variação das exportações da China, Coreia do Sul, Rússia e Brasil.

De maneira geral, o método de CMS se mostrou uma abordagem quantitativa eficiente, que fornece um panorama descritivo detalhado dos padrões de comércio. Embora não explicite os fatores determinantes do efeito competitividade, o modelo de CMS é uma ferramenta exploratória de análise eficiente, pois ao delimitar a participação da competitividade no crescimento das exportações, proporciona um ponto de partida para uma análise mais acurada nos termos sugeridos por Ahmadi-Esfahani (2006).

Estas conclusões abrem caminho para algumas propostas de trabalhos futuros. Em primeiro lugar, parece interessante investigar os determinantes da competitividade da China, tendo em vista que este país apresentou o melhor resultado nesse componente, entre os sete analisados. Além disso, entre os países estudados, a China foi o único que passou por um nítido processo de diversificação da pauta de exportações e apresentou efeito competitividade positivo em todos os anos, o que indica que o país possui atributos competitivos de diversas ordens.

Outro ponto de interesse nesse trabalho é que os resultados observados apontaram para uma correlação negativa entre um maior conteúdo tecnológico da pauta exportadora e o desempenho comercial. Isso se deve, em parte, ao movimento conjuntural de crescimento da demanda internacional por commodities no período estudado. Há convergência com os resultados do estudo de Fagerberg e Srholec (2004), que apontaram que os países menos avançados apresentam uma capacidade de adaptação às novas tecnologias superior à dos países desenvolvidos. Isso decorre do fato de os países menos desenvolvidos empregarem tecnologias elaboradas nos países desenvolvidos, sem precisarem arcar com o processo de descoberta de custos (Hausmann; Hwang; Rodrik, 2005) ou esperar o tempo de maturação do investimento em tecnologia.

Estas constatações conduzem a um questionamento importante sobre a dinâmica recente do comércio exterior. Visto que uma parte considerável da transferência de tecnologias é feita via investimento estrangeiro direto (IED), é possível que o deslocamento de multinacionais de países desenvolvidos (como Estados Unidos e Japão) para economias menos desenvolvidas (como China, Brasil e Coreia do Sul) esteja resultando também em uma "transferência de 
competitividade". Esta hipótese aponta para um novo caminho no estudo da competitividade internacional, em que se dá maior atenção aos fluxos de IED como fatores determinantes do desempenho competitivo. Uma pesquisa desse tipo pode fornecer respostas acerca dos ganhos de competitividade da Coreia do Sul e da China frente às perdas registradas pelo Japão e das perdas de competitividade dos Estados Unidos.

Para o caso específico do Brasil, os resultados apresentados vão ao encontro do debate em torno das vantagens e desvantagens da especialização ou da diversificação produtiva e de comércio internacional (Bresser-Pereira, 2010; Bacha; Bolle, 2013). Longe de resolver o debate, as evidências empíricas obtidas revelam que o bom desempenho exportador brasileiro no período em tela se deveu aos efeitos de expansão do mercado internacional com especialização setorial e regional nos segmentos que apresentaram maior dinamismo no período, a saber, a venda de recursos naturais e a diversificação de destinos com ênfase nos mercados emergentes.

\section{Referências bibliográficas}

AHMADI-ESFAHANI, F. Z. Constant market shares analysis: uses, limitations and prospects. The Australian Journal of Agricultural and Resource Economics, 50, p. $510-526,2006$.

BACHA, E.; BOLLE, M. B. (Org.). O futuro da indústria no Brasil: desindustrialização em debate. Rio de Janeiro: Civilização Brasileira, 2013.

BERTOLLI, S.; MEDEIROS, N. H. Evolução da competitividade da indústria brasileira: uma análise a partir do movimento de reestruturação setorial nos anos 90. In: ENCONTRO SOBER, 48, 2003. Disponível em: http://www.aph.gov.au/library/ pubs/rn/1995-96/96rn54.pdf. Acesso em: 25 fev. 2012.

BRESSER-PEREIRA, L. C. (Org.). Doença holandesa e indústria. Rio de Janeiro: Editora FGV, 2010.

CANUTO, O.; XAVIER, C. L. Specialization and competitiveness in Brazilian foreign trade. Momento Económico, México, v. 119, p. 24-34, 2002.

CARVALHO, F. M. A. de. Método "Constant Market Share” (CMS). In: SANTOS, M. L. dos; VIEIRA, W. da C. Métodos quantitativos em economia. Viçosa: UFV, 2004. cap. 8, p. 225-241.

FAGERBERG, J.; SRHOLEC, M. Structural changes in international trade: cause, impact and response. Revue Économique, v. 55, p. 1071-1097, 2004.

GARELLI, S. Competitiveness of nations: the fundamentals. International Institute for Management Development, 2002. 
GUIMARÃES, E. P. Competitividade internacional: conceitos e medidas. Estudos em Comércio Exterior, Rio de Janeiro, v. I, n. 3, p. 1-25, 1997.

HAGUENAUER, L. Competitividade: conceitos e medidas. Uma resenha da bibliografia recente com ênfase no caso brasileiro. Rio de Janeiro: UFRJ. IE, 1989. (Texto para discussão, n. 211).

HAUSMANN, R.; HWANG, J.; RODRIK, D. What you export matters. Cambridge: NBER Working Paper Series, 2005. p. 1-14. (Working Paper, 11905).

HOLLAND, M.; XAVIER, C. L. Dinâmica e competitividade setorial das exportações brasileiras: uma análise de painel para o período recente. Anais do In: ENCONTRO NACIONAL DE ECONOMIA, 32, João Pessoa, PB, 2004. Anais... Niterói: Associação Nacional de Centros de Pós-Graduação em Economia - Anpec, 2004.

IGLESIAS, R. M.; RIOS, S. P. Desempenho das exportações brasileiras no pósboom exportador: características e determinantes. Estudo Cindes, set. 2010. Disponível em: $\underline{w w w . c i n d e s b r a s i l . o r g}$.

IMBS, J.; WACZIARG, R. Stages of diversification. The American Economic Review, v. 93, n. 1, p. 63-83, 2003.

KRUGMAN, P. Making sense of the competitiveness debate. Oxford Review Economic Policy, v. 12, n. 3, 1996.

Rethinking international trade. Cambridge: MIT Press, 1990.

KUPFER, D.; HASENCLEVER, L. (Org.). Economia industrial. Rio de Janeiro: Campus, 2013.

LEAMER, E.; STERN, R. Constant-market-share analysis of export growth. In: (Org.). Quantitative international economics. Boston: Allyn and Bacon, 1970. Cap. 7, p. 171-183.

MARKWALD, R.; RIBEIRO, F. Expansão das exportações: quais as alternativas. In: FÓRUM NACIONAL, 22, Instituto Nacional de Altos Estudos, Rio de Janeiro, 2010 .

PEREIRA, L. V.; SOUZA, A. L. S. de. Exportações brasileiras na primeira década do século XXI: desempenho e fontes de crescimento. In: BONELLI, R. (Org.). A agenda de competitividade do Brasil. Instituto brasileiro de Economia. Rio de Janeiro: Editora FGV, 2011. Cap 11, p. 323-378.

PINHEIRO, A. C.; BONELLI, R. Comparative advantage or economic policy? Stylized facts and reflections on Brazil's insertion in the world economy - 19942005. Rio de Janeiro: Ipea, abr. 2007. (Texto para Discussão, n. 1275a). 
PINHEIRO, A. C.; BONELLI, R. Competitividade: significados, dimensões, aplicações. In: BONELLI, Regis (Org.). A agenda de competitividade do Brasil. Instituto brasileiro de Economia. Rio de Janeiro: Editora FGV, 2011. Cap. 1, p. 4159.

POSSAS, S. Concorrência e competitividade: notas sobre a estratégia e dinâmica seletiva na economia capitalista. São Paulo: Hucitec, 1999.

REIS, J. G.; FAROLE, T. Trade and the competitiveness agenda. Economic Premisse - The World Bank, n. 18, p. 1-5, 2010.

RICHARDSON, J. D. Constant-market-shares-analysis of export growth. Journal of International Economics, Wisconsin, I, p. 227-239, 1971.

RODRIK, D. Políticas de diversificação econômica. Revista Cepal, Comissão Econômica para a América Latina e o Caribe, jun. 2010.

TYSZYNSKI, H. World trade in manufactured commodities, 1899-1950. The Manchester School, v. 19, ed. 3, p. 272-304, Sept. 1951.

UNIDO. Competitive industrial performance report 2012/2013. Vienna: United Nations Industrial Development Organization, 2013.

WTO. A practical guide to trade policy analysis. World Trade Organization, 2012. 


\section{Anexo}

\section{Gráfico A1}

Participação das fontes do crescimento em economias selecionadas - acumulado 2001-2011
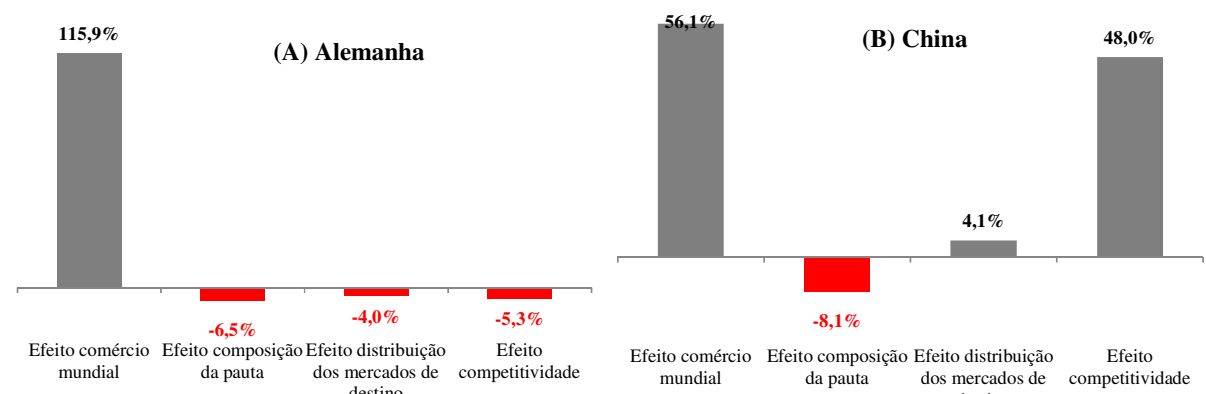

Efeito comércio Efeito composição Efeito distribuição Efeito mundial da pauta dosmercados de competitividade
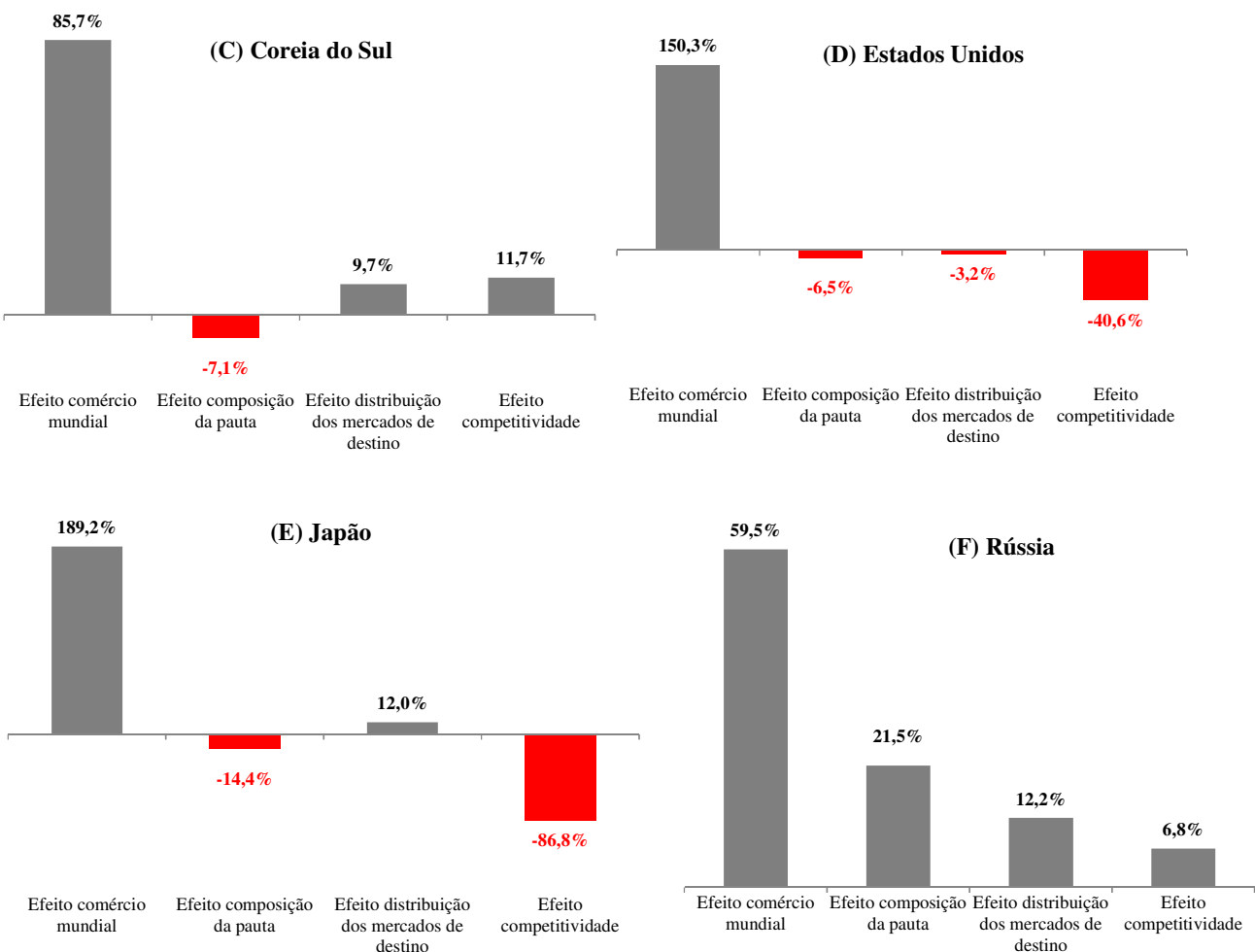

Fonte de dados brutos: UN Comtrade. 
Gráfico A2

Evolução do market-share setorial nas economias selecionadas, 2000-2011(\%)

(A) Alemanha

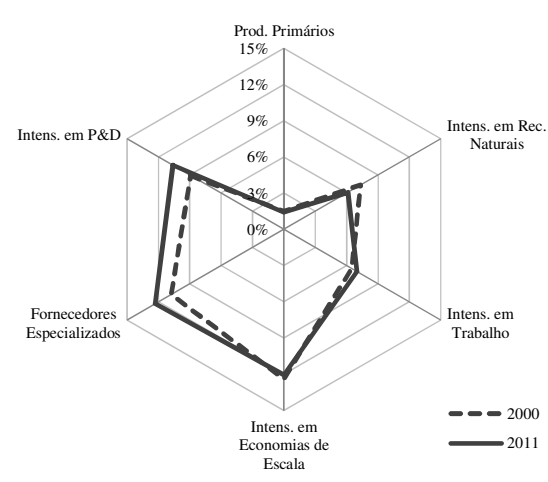

(C) Coreia do Sul

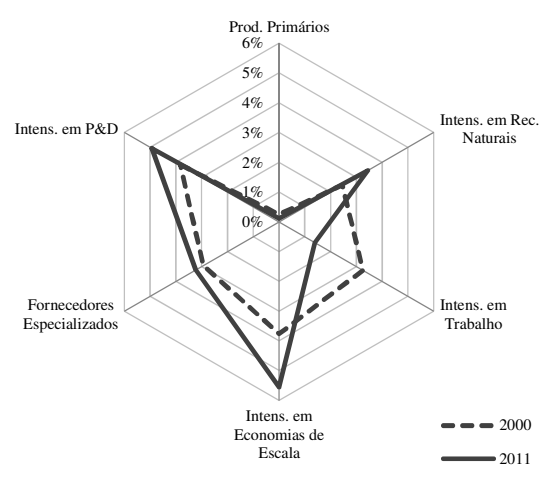

(E) Japão

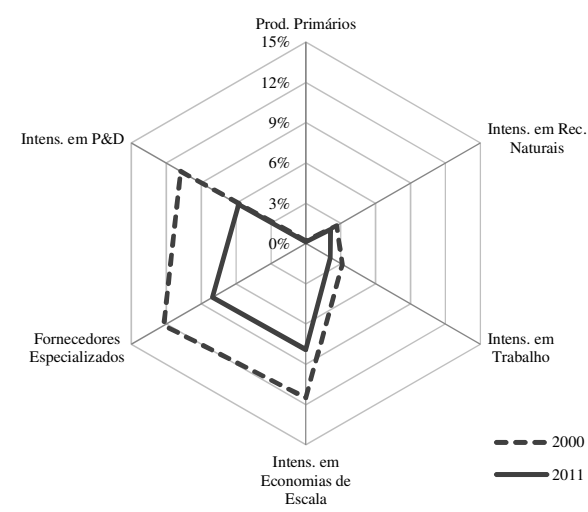

(B) China

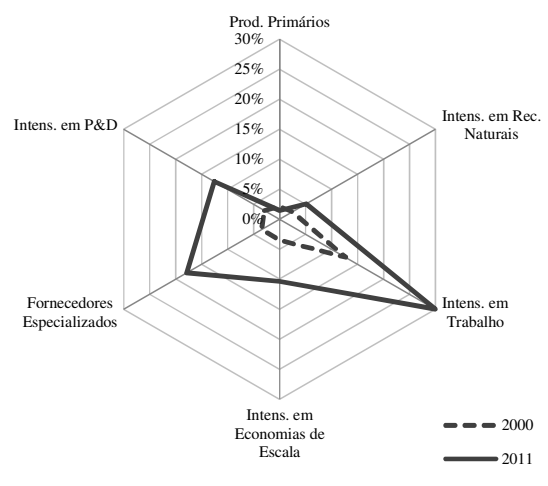

(D) Estados Unidos

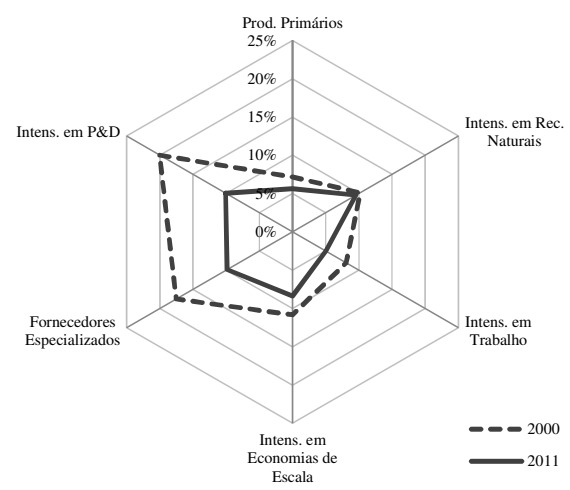

(F) Rússia

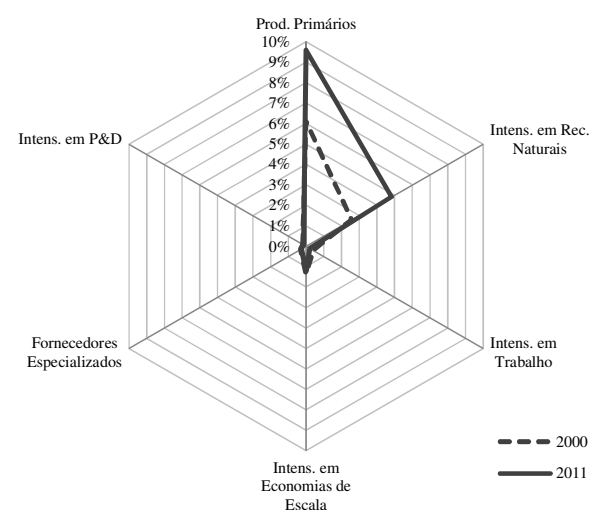

Fonte de dados brutos: UN Comtrade. 